\title{
Mimetyczna pokusa apokalipsy
}

Edwin Bendyk

TEKSTY DRUGIE 2020, NR 1, S. 259-267

DOI: $10.18318 /$ td.2020.1.15

$A^{\prime}$ pokalipsa tu i teraz to ostatnia książka René Girarda' Przygotował ją w formie rozmowy, którą animował Benoît Chantre. Francuski oryginał został opublikowany w 2007 roku jako Achever Clausewitz ${ }^{2}$, czyli „Dokończyć Clausewitza". Nie tylko polski wydawca zdecydował się na zmianę oryginalnego tytułu, przekład angielski to Battling to the End³ , czyli „Prowadząc bitwę aż do końca”. Nie wiem, czym były podyktowane tak duże ingerencje, skoro odciągają one od istoty przekazu, jaki wyłania się z rozmowy-rzeki. Carl von Clausewitz jest tego dialogu głównym bohaterem, a znaczenie mają zarówno jego myśl, jak i biografia.

1 R. Girard Apokalipsa tu i teraz. Rozmowa z Benoît Chantre, przeł. C. Zalewski, Wydawnictwo WAM, Kraków 2018.

2 R. Girard Achever Clausewitz, Entretiens avec Benoit Chantre, Carnets Nord, Paris 2007.

3 R. Girard Battling to the End. Conversations with Benoit Chantre, trans. M. Baker, Michigan State University Press, East Lansing, 2010.
Edwin Bendyk

(ur. 1965) - dziennikarz, publicysta i pisarz. Wykładowca akademicki, kierownik działu naukowego tygodnika „Polityka”. Autor wielu książek. Członek Polskiego PEN-Clubu. Prowadzi blog "Antymatrix". 
Po kolei jednak. René Girard jest doskonale znany polskim czytelnikom z wielu przekładów, Kozioł ofiarny ${ }^{4}$ i Sacrum i przemoc ${ }^{5}$ miały status lektur wręcz kultowych, a tezy francuskiego antropologa mocno, choć nie bez dyskusji i sporów, weszły do humanistycznego słownika. Girard jest twórcą teorii mimetycznej, która w pasji naśladowczej upatruje głównego mechanizmu rozwoju relacji społecznych. Antropolog nie był pionierem ujęcia mimetycznego, miał wielkiego poprzednika w postaci Gabriela Tarde'a, autora Les lois de l'imitation ${ }^{6}$ [Prawa imitacji], który z mimetyzmu wywodził ludzką zdolność do kreowania innowacji.

Girard w mimetyzmie doszukuje się jednak źródeł przemocy, a samą pasję mimetyczną lokuje u źródeł religii i kultury. I właśnie dlatego francuski antropolog, jeden z najważniejszych badaczy zjawiska przemocy, musiał odkryć Clausewitza, autora traktatu $O$ wojnie ${ }^{7}$, i zafascynować się nim. Dzieło nie zostało dokończone, pracę pruskiego wojskowego przerwała przedwczesna śmierć na skutek zarażenia cholerą. To jednak, co się ukazało, jest do dziś pilnie studiowane nie tylko przez wojskowych. Bo $O$ wojnie to dzieło na wskroś nowoczesne i ciągle aktualne, w którym spod rozważań o wojnie i strategii wyłania się głęboka myśl antropologiczna, społeczna i polityczna.

Clausewitz w swych rozważaniach o wojnie i przemocy jako instrumencie polityki stosowanym podczas wojennej rozgrywki odkrywa bliskie Girardowi prawa rządzące pasją naśladowczą. Najważniejsze z tych praw mówi, że wojenne użycie przemocy musi prowadzić do eskalacji konfrontacji aż do wyczerpania potencjału jednej ze stron konfliktu. Clausewitz dostrzega to samo, co Girard - raz uruchomiony diabelski krąg przemocy nie zna innego końca niż na skutek wyczerpania podsycającej go energii. Doskonale pokazuje tę wyniszczającą logikę trwająca setki lat vendetta, która zobowiązuje skłócone korsykańskie rody do odpłaty na zasadzie wet za wet, mimo że już mało kto zna pierwotną przyczynę waśni. Dlaczego jednak ludzkość do dziś się nie wyrżnęła, skoro pasja mimetyczna ma taką siłę?

Bo, jak pokazuje Girard, przemoc należy do porządku kultury, a nie natury. Nie należy jej zatem mylić z naturalną agresją. Agresja może być instrumentem przemocy, sama jednak przemoc jest konstruktem kulturowym

\footnotetext{
4 R. Girard Koziołofiarny, przeł. M. Goszczyńska, Wydawnictwo Łódzkie, Łódź 1987.

5 R. Girard Sacrum i przemoc, przeł. M. Plecińska, Nomos, Poznań 1993.

6 G. Tarde Les lois de l'imitations, b.n.w., Paris 2001.

7 C. von Clausewitz O wojnie, przeł. A. Cichowicz, L. Koc, Wydawnictwo MON, Warszawa 1958.
} 
i podlega kulturowej kontroli, a jednymi z jej najważniejszych regulatorów są religia i rytuały ofiarnicze. Rzeczywista lub symboliczna krew ofiary odnawia wspólnotę, uwalniając ją od niszczących pasji. W tym porządku największym wydarzeniem ratowania ludzkiego świata przed samozagładą była ofiara Chrystusa, która miała uwolnić ludzkość od negatywnego mimetyzmu przemocy i zastąpić go pozytywnym mimetyzmem chrześcijańskiej miłości.

Clausewitz zwraca z kolei uwagę, że przemoc i wojna należą do sfery polityki, w której namiętności podporządkowane są celowi politycznemu. Przemoc nigdy nie jest celem samym w sobie, tylko środkiem do celu. Clausewitz pisał swoje rozważania wyraźnie zafascynowany Napoleonem. Cesarz Francuzów na zawsze zmienił charakter wojny i pokazał jej totalny charakter, gdy zostaje wprzęgnięta w dzieło konstruowania nowego, uniwersalistycznego ładu na świecie.

Girard, czytając Clausewitza, nie przyjmuje do wiadomości, że pruski generał był człowiekiem oświecenia, i dopatruje się w jego dziele wybitnie religijnych interpretacji przemocy. Jednocześnie zwraca uwagę na osobisty motyw, który kierował Clausewitzem - za fascynacją krył się resentyment. To właśnie ów ucieleśniony przez Prusaka resentyment stał się głównym mechanizmem napędzającym historię uniwersalną od bitwy pod Jeną po kapitulację Francji w 1940 roku. Ów niemiecki resentyment wobec Francji i wynikająca z niego pasja naśladowcza doprowadziły do kolejnych, coraz bardziej bezwzględnych przesileń.

Opowieść o francusko-niemieckich relacjach w XIX i XX wieku, pełna odniesień historycznych i kulturowych, jest erudycyjnym fajerwerkiem. Abstrakcyjne kategorie antropologiczne nagle ożywają pod postacią konkretnych wydarzeń, dzieł kultury i osób w wielkim dziejowym procesie, w którym odsłania się coraz wyraźniej horyzont apokalipsy. Bo zdaniem Girarda nie tylko nie potrafiliśmy wyciągnąć właściwej lekcji z chrześcijaństwa, marnując daną szansę, ale także odwracamy wzrok od jednoznacznych sygnałów podrzucanych przez historię: Verdun, Holokaust, 11 września 2001 roku oraz powrót języka wojen religijnych do polityki, w końcu globalne ocieplenie to wszystko coraz wymowniej przypomina, że objawienie św. Jana nie było tylko abstrakcyjnym, wyrwanym z dziejowej logiki tekstem, lecz jest zapowiedzią możliwego końca historii. Tylko że nie w wersji radosnej à la Francis Fukuyama, lecz dosłownej - jako zapowiedź końca ze względu na samozagładę podmiotu historii, gatunku ludzkiego.

Warto przypomnieć, że w roku 2007 - momencie publikacji Achever Clausewitz - ciągle jeszcze żywe były wspomnienia zamachu 11 września 2001 
roku na World Trade Center i Pentagon. Traumę samego ataku przesłaniały jednak coraz bardziej realia „wojny z terrorem”, która w praktyce oznaczała niezwykle kosztowne i krwawe zaangażowanie Stanów Zjednoczonych i ich sojuszników w Iraku i Afganistanie. Z drugiej jednak strony w 2007 roku trwał jeszcze boom gospodarczy, nikt nie wyobrażał sobie nadciągającego kryzysu finansowego. Zmiany klimatyczne, owszem, były już przedmiotem poważnych debat, ale ciągle jeszcze trwających bez poważniejszego zaangażowania szerokiej opinii publicznej. W takim kontekście apokaliptyczny ton Achever Clausewitz można było odczytywać jako wyraz zgorzknienia sędziwego myśliciela (Girard zmarł w 2015 roku w wieku 92 lat), który choć nie mógł narzekać na brak zainteresowania, to jednak cierpiał, że mało kto właściwie rozumiał istotę jego przekazu.

Apokalipsa tu i teraz, polski przekład książki Girarda i Chantre'a, ukazał się w roku 2018. Minęła zaledwie dekada, a w jakże innym świecie żyjemy. A rok 2018 można uznać za czas, kiedy apokalipsa opuściła słownik katastrofistów, wkraczając do języka codziennej debaty. Na takie przyspieszenie złożyło się kilka czynników. Po pierwsze, Międzyrządowy Panel ds. Zmian Klimatycznych ONZ (IPCC), ciało naukowe wspierające Ramową Konwencję ONZ ds. Zmian Klimatycznych (UNFCC), ogłosił jesienią raport specjalny Globalne ocieplenie 1,5 st. C. Naukowcy pracujący pod auspicjami IPCC podsumowali w nim stan wiedzy dotyczący możliwości osiągnięcia celu wskazanego w Porozumieniu paryskim z 2015 roku. Dokument wskazuje, że należy dążyć do ograniczenia średniego wzrostu temperatury atmosfery o $1,5^{\circ} \mathrm{C}$ w stosunku do okresu przedprzemysłowego. Za granicę mniej korzystną, ale jeszcze akceptowalną Porozumienie wskazało $2^{\circ} \mathrm{C}$.

Raport specjalny z 2018 roku pokazał wyraźnie, co oznacza w wymiarze realnych konsekwencji różnica zaledwie $0,5^{\circ} \mathrm{C}$ - między 1,5 a $2^{\circ} \mathrm{C}$. Jednocześnie też jego autorzy przypomnieli, że do osiągnięcia pożądanego celu zostało niezwykle mało czasu - do 2030 roku należałoby zmniejszyć globalne emisje gazów cieplarnianych o ponad połowę, a do 2050 roku uzyskać neutralność klimatyczną. Punkt czasowy „Rok 2030” zaczął żyć własnym życiem, oderwany od naukowego kontekstu stał się wręcz prognozą terminu apokalipsy. Zaczęło się wielkie odliczanie, któremu towarzyszy jednak „marazm antropocenu". To pojęcie zaproponowane przez Ewę Bińczyk ${ }^{8}$. Filozofka opisuje nim niezdolność ludzi, mimo istnienia niezbędnej i wystarczającej wiedzy, do podjęcia działań adekwatnych do skali wyzwań i naukowych rekomendacji.

8 E. Bińczyk Epoka człowieka. Retoryka i marazm antropocenu, PWN, Warszawa 2018. 
Przeciwnie, idziemy ciągle ścieżką business as usual, której głównym wyznacznikiem jest wzrost gospodarczy, oznaczający zwiększone zużycie energii i w konsekwencji wzrost globalnej emisji gazów cieplarnianych.

Przekaz naukowy, nawet udramatyzowany (choć autorzy IPCC unikają tanich efektów komunikacyjnych) i przeinterpretowany przez media nie wywołałby aż takiego poruszenia, gdyby nie towarzyszył mu Znak Czasów, czyli Posłaniec z Przyszłości, jak Przemysław Czapliński nazwał Gretę Thunberg. Thunberg rozpoczęła swą misję w sierpniu 2018 roku, samotnie podejmując strajk szkolny dla klimatu w Sztokholmie. Nikt nie mógł wtedy przypuszczać, że już w grudniu będzie oficjalnym gościem Szczytu Klimatycznego COP24 w Katowicach, a potem ruszy dalej - do papieża Franciszka i na Światowy Szczyt Ekonomiczny w Davos.

Przekaz nastoletniej aktywistki jest prosty: przybywam, żebyście zaczęli panikować, bo my, młodzi, odczuwamy panikę przed światem, jaki nam zostawicie i w którym mamy dorastać. Nasz dom płonie, czas działać, a nie gadać. Starsi komentatorzy porównują Szwedkę do Joanny d'Arc, inni pomstują na zinfantylizowany świat, w którym ton debacie zaczęły nadawać dzieci, uruchamiając cały autentyzm swoich niedojrzałych jeszcze emocji. Problem w tym, że emocje Thunberg są niczym wobec histerycznych tweetów Donalda Trumpa. Prezydent USA na lewo i prawo wysyła groźby pod adresem tych, którzy ośmielą się przeciwstawić potędze Ameryki. Nie zważa przy tym zupełnie na fakty, naukę czy normy prawne.

Greta Thunberg z kolei kończy zawsze swoje tyrady prostym komunikatem: trzeba robić to, co mówi nauka. Jej ustaleń nie da się zamieść pod dywan. A nauka i naukowcy coraz częściej rzeczywiście zaczynają zwracać uwagę na możliwość „przestrzelenia”. To sytuacja, w której na skutek zmian klimatycznych dochodzi do sprzężeń zwrotnych powodujących przyspieszenie procesu. Stawkę tego zagrożenia przedstawił głośny artykuł w „Nature”10 opublikowany tuż przed Szczytem Klimatycznym COP25 w Madrycie. Autorzy, renomowani badacze klimatu, zwracają uwagę na to, że już nie można wykluczyć powstawania lokalnych sprzężeń, np. efektów topnienia wiecznej zmarzliny i uwalniania się z niej gazów cieplarnianych. W efekcie okienko działania wyznaczone do 2030 roku, by zatrzymać wzrost temperatury na poziomie $1,5^{\circ} \mathrm{C}$, może już się zamykać.

9 Wypowiedź podczas debaty "Odwieczny las”, Warszawa 26 kwietnia 2019 roku. 
Aby zmierzyć się z wyzwaniem apokalipsy tu i teraz, musimy wrócić do książki Girarda. Otóż autor jawi się jako myśliciel głęboko antyoświeceniowy, który wyjaśnia współczesne zagrożenie apokalipsą nie tylko czynnikami ekologicznymi, ale szerzej, kwestią dla niego zasadniczą - uwolnieniem się przemocy spod kontroli kultury. Wojny napoleońskie były tylko zapowiedzią przemysłowych rzezi I wojny światowej, kiedy zgodnie ze stwierdzeniem Clausewitza strony konfliktu w mimetycznym szaleństwie angażowały wszystkie zasoby nowoczesnej cywilizacji, by nawzajem się wyniszczyć. Rozstrzygnięcie nie było jednoznaczne: Niemcy nie zostali pokonani, jednak musieli przyjąć warunki pokoju, o których zadecydował francuski resentyment. Ziarno II wojny światowej i totalitaryzmów zostało posiane.

Girarda najbardziej boli zagubienie przez człowieka współczesnego zadania, jakie wyznaczyła chrześcijańska rewolucja - zastąpienia mimetyzmu przemocy mimetyzmem miłości. Dręczy go Schadenfreude, z jaką koledzy akademiccy ogłaszają kolejne triumfy sekularyzacji Zachodu, nie dostrzegając w pełni apokaliptycznego potencjału wojowniczego islamu. Jak to jednak wszystko połączyć: kryzys ekologiczny, anomiczną eskalację przemocy i apokalipsę? Girard słusznie podpowiada, że apokalipsa nie będzie miała charakteru katastrofy ekologicznej - kresu ludzkości nie przyniesie potop spowodowany przez podnoszące się oceany ani nadmierne temperatury. Zabójcza będzie polityczna na nie reakcja. Na dowód wystarczy przywołać przykład Syrii, w której od roku 2011 trwa krwawa wojna domowa - głównym czynnikiem, który doprowadził do użycia i eskalacji przemocy, były zmiany klimatyczne.

Girard, przypomnijmy, pisał w 2007 roku. Rubaszni polscy prawicowi i liberalni komentatorzy lubili wówczas nazywać aktywistów ekologicznych ekofaszystami. Dziś ekofaszyzm ma już bogatą literaturę i nie odnosi się jedynie do ruchów dopuszczających przemoc w walce o cele ekologiczne. Zabójcy z Christchurch i El Paso sami określali się ekofaszystami, rozumiejąc przez to ideologię eksterminacyjną zakładającą, że ratunek dla ludzkości wiedzie przez eliminację nadmiaru ludności. Łagodniejsze formy odkrywania potencjału tematyki ekologicznej przez prawicę widać wyraźnie na europejskiej scenie politycznej. Austriacki sojusz „czarnych" z „zielonymi” ma na celu ochronę "przyrody i granic”. Zgromadzenie Narodowe Marine Le Pen bez żadnych sojuszy wprowadza do gry ekologiczną kartę. Podobnie prawicowi populiści na Węgrzech. Apokalipsa więc, jeśli do niej dojdzie, będzie wydarzeniem politycznym, podczas którego polityka będzie kontynuowana innymi środkami, czyli mobilizacją przemocy. 
Czy wobec takiego dictum jesteśmy bezradni? Warto pospierać się trochę z Girardem, odrzucając jego eschatologiczny fatalizm. Antropolog upatrywał źródła przemocy w kulturze i religii, w nich też widział najskuteczniejsze metody kontroli mimetycznej pasji zniszczenia. Możliwa jest jednak inna interpretacja, wynikająca z oświeceniowego odczytania Clausewitza. Przemoc jest paradoksalnym skutkiem ludzkiej racjonalności. Wiele na ten temat dowiedzieliśmy się z teorii gier, którą namiętnie wykorzystywano m.in. do planowania politycznego w sytuacji zagrożenia wojną termojądrową.

Rozum podpowiada, aby w sytuacji ograniczonych zasobów ruszyć pierwszemu i z nich skorzystać. Odpowiedzią jest mimetyczne działanie innych konkurentów do tych samych zasobów. W efekcie dochodzi do zjawiska opisanego przez Garreta Hardina w 1968 roku11 - tragedii wspólnego pastwiska, czyli nadmiernego zużycia zasobów i kryzysu, który dotyka wszystkich uczestników gry. Hardin w odpowiedzi na tę tragedię znalazł rozwiązanie: albo przemoc państwa, które pilnuje reguł korzystania z zasobów, albo przemoc prawa - czyli prywatyzacja pastwiska i powierzenie go prywatnej pieczy w ramach prawa własności.

Mechanizmy stosowania przemocy, co dobrze pokazuje paradoks więźnia, sprowadzają się do podobnej zasady. Gdy nie wiem, jakie zamiary ma przeciwnik, ale mogę podejrzewać go o interes w zaatakowaniu mnie, rozsądne jest uprzedzenie ataku. Sytuacja skomplikowała się wraz z pojawieniem się broni termojądrowej. Apokaliptyczne konsekwencje ewentualnej wojny termojądrowej doprowadziły do wypracowania złożonych relacji postępowania między adwersarzami, USA i ZSRR. Zasada MAD - mutually assured destruction - ochroniła świat przed wojną światową, choć opiera się na niezwykle karkołomnej konstrukcji.

W świecie nasyconym bronią termojądrową nikt nie ma interesu w rozpoczynaniu wojny nuklearnej, co jednak nie wyklucza opisanego wcześniej paradoksu rozumu: a co, jeśli komuś wpadnie myśl, żeby z jakichś powodów zaatakować? Przed atakiem powstrzymuje go pewność mimetycznej odpowiedzi adwersarza. Atak uprzedzający nic nie da, gdy towarzyszy mu pewność, że w odpowiedzi zostaną zniszczone najważniejsze ośrodki atakującego. Skrajny wyraz zasady MAD pokazał Stanley Kubrick w filmie Dr. Strangelove, czyli jak przestałem się martwić i pokochałem bombę.

Nie religia więc, tylko chłodna racjonalna kalkulacja chroni na razie świat przed zagładą. Przynajmniej w wymiarze nuklearnym. Francuski

11 G. Hardin Tragedy of the Commons, "Science” 1968 No. 162 (3859), 1243-1248. 
filozof Jean-Pierre Dupuy ${ }^{12}$ rozwija koncepcję „katastrofizmu oświeconego”. To w sumie optymistyczna odpowiedź na pokusę myślenia apokaliptycznego. Dupuy analizuje nie tylko zasadę działania doktryny MAD, ale także przypomina zasadę odpowiedzialności Hansa Jonasa. Nie jest ona dyrektywą tak brutalną, jak MAD, ale wywodzi się z podobnego myślenia. W uproszczeniu podstawą zasady odpowiedzialności jest heurystyka strachu. Polega ona na zawieszaniu działań, np. rozwoju technologii, jeśli nie jesteśmy pewni skutku ich upowszechnienia w przyszłości, a istnieją probabilistyczne przesłanki wskazujące, że skutki mogą być katastrofalne i nieodwracalne.

Czas na ostatni element apokaliptycznej łamigłówki. Zasada odpowiedzialności dziś nam na nic, bo przecież nie chodzi o powstrzymanie się od działania, tylko o mobilizację do działania na rzecz klimatu i ochrony przyszłości. Czy heurystyka strachu i sianie paniki mogą odnieść skutek mobilizujący? Niestety, doświadczenie pokazuje, że specjalistami od stosowania heurystyki strachu w polityce pozytywnej, czyli wzywającej do działania, są dziś prawicowi populiści. Oni najlepiej potrafią przekodować strach na polityczne paliwo. A za nimi, o czym była już mowa, stoją w kolejce i czekają na swój czas ekofaszyści.

Jean-Pierre Dupuy znajduje jednak ścieżkę wyjścia z tej, wydawałoby się, matni bez wyjścia. Podobnie jak przed powstrzymywaniem się od działania $\mathrm{w}$ ramach zasady odpowiedzialności ma chronić prawdopodobieństwo negatywnych konsekwencji, tak do działania na rzecz zmiany ma motywować prawdopodobieństwo istnienia pozytywnych scenariuszy. Opracowania naukowe nie posługują się językiem pewności, tylko prawdopodobieństwa. W 2030 roku świat się nie skończy, choć rzeczywiście trudniej będzie go uratować.

Apokaliptycy w swej argumentacji często przywołują argument, że realizujemy wspomniany scenariusz business as usual, czyli brniemy starymi koleinami ku zagładzie. Nic bardziej mylnego, scenariusze business as usual wykorzystywane w analizach strategicznych mają jedynie funkcję informacyjną są abstrakcyjnym, konserwatywnym punktem odniesienia, co się stanie, jeśli nic się nie zmieni. Tyle tylko, że zmiany są nieuniknione ze względu choćby na nieprzewidywalność procesu innowacyjnego. Nie chodzi o to, by od razu zakładać, że uratuje nas cudowna technologia. Ale inkrementalne zmiany w różnych polach techniki, życia społecznego i świadomości przekładają się na zmianę systemową, której efektem jest realny scenariusz rozwojowy.

12 J.-P. Dupuy Pour un catastrophisme éclairé, Éditions du Seuil, Paris 2004. 
Czy te zmiany będą wystarczające? Oczywiście nie sposób przewidzieć dynamiki rozwoju systemu złożonego. Historia jednak podpowiada, że systemy takie odpowiadają zarówno poprzez działania mitygacyjne, jak i adaptacyjne, uruchamiając zasoby odporności na niekorzystne impulsy. Dyrektywa, by działać szybko, bo przecież doskonale wiadomo, co trzeba zrobić, by ustrzec się przed apokalipsą, jest najlepszą receptą na samospełniającą się przepowiednię. Rozsądniejsze jest skorzystanie z tego przeżytku oświecenia, rozumu katastroficznego, który kieruje się zasadą "pewne jest to, co niemożliwe”. Nie bagatelizując ryzyka, nie lekceważmy potencjału pozytywnej alternatywy.

\section{Abstract}

\section{Edwin Bendyk}

The Mimetic Temptation of the Apocalypse

Bendyk discusses two interpretations of violence and its sources. The first refers to René Girard's mimetic theory, where violence is a product of religion and culture; and the second stems from the Enlightenment, which presents violence as a product of human rationality. In Girard's interpretation the apocalypse is a real option for the end of history, the second one leads to enlightened catastrophism, which removes the necessity of the apocalypse.

\section{Keyword}

sviolence, apocalypse, catastrophism, Enlightenment, religion, culture, rationality, mimetism, war, future, ecology, mind 